\title{
ANXA5 wt Allele
}

National Cancer Institute

\section{Source}

National Cancer Institute. ANXA5 wt Allele. NCI Thesaurus. Code C51086.

Human ANXA5 wild-type allele is located within 4q27 and is approximately $29 \mathrm{~kb}$ in length.

This allele, which encodes annexin A5 protein, plays a role in cellular signal transduction, inflammation, growth and differentiation. 